\title{
A Transnational Triangle Representations of the EU and Serbia in the Narratives of Bosnian Serbs Living in Graz
}

DOI 10.17234/9789531756525.4

Marija Brujić

Institute of Ethnology and Anthropology, Faculty of Philosophy, University of Belgrade

Čika Ljubina 18-20, 11000 Belgrade, Serbia

marija.brujic@f.bg.ac.rs

As part of my research on cultural representations of the European Union and of Serbia's EU integration process among the Serbian diaspora in Austria, I discuss the narratives of Bosnian Serbs living in Graz. Their "cultural knowledge" of Serbian foreign policy can, at the same time, be analysed in light of understanding their ambivalent "neither, nor" position. Therefore, using the concept of a "transnational way of belonging", I argue that their narratives regarding Serbia's future and of the disadvantages of EU membership for Serbia can be interpreted as transnational practices which connect them with their country of historical origin.

Keywords: cultural representations, Bosnian Serbs, "transnational way of belonging”, European Union, EU integration

\section{Introduction $^{1}$}

erbs represent one of the largest foreign ethnic groups in Austria, due to their centuries-long settlement on the territory of the Habsburg Monarchy, dat$\checkmark$ ing from the sixteenth century, along with later migrations to Austria, especially during the "so-called Gastarbeiter period" from 1955 till 1973 (Grečić and Lopušina 1994: 112-113; Payer 2004; Ivanović 2012). According to the Austrian statistical yearbook, in 2014 there were 114,000 Serbs and 93,000 Bosnians (Serbs, Croats and Bosniaks/Bosnian Muslims) living in Austria (Baldaszti et al. 2015: 26). Bearing these facts in mind, in socio-cultural anthropology there is currently a

\footnotetext{
This paper is the result of research conducted in Graz enabled by a "one-month visit" scholarship from the Austrian Federal Ministry of Science and Research and work on a project entitled "The Identity Politics of the European Union: Its Adaptation and Application in the Republic of Serbia" (177017) organised by the Ministry of Education, Science and Technological Development of the Republic of Serbia. I would like to express my deepest gratitude to Prof. Helmut Eberhart from Karl Franzens University - who supervised my fieldwork - for his professional help, beneficial comments and kind advice.
} 
growing interest in Serbs living in Austria. ${ }^{2}$ However, such anthropological research primarily focuses on Serbian guest workers. By contrast, I have conducted research with Serbs who voluntarily decided to emigrate from Serbia during the last two or three decades and settle in Austria (Brujić 2015b). In 2013, with this goal in mind, I conducted micro level qualitative research among Serbs living in Graz. Given that EU integration is currently one of the most important strategic goals of Serbian foreign policy, ${ }^{3}$ I focused on cultural representations of the EU and of the EU integration of Serbia among Serbs living in the EU (Brujić 2018). Although my main target group were Serbs from Serbia, some Serbs, originally from Bosnia and Herzegovina (the Republic of Srpska entity), ${ }^{4}$ wished to participate arguing that "we are all Serbs, we are one people". Therefore, in this paper I intend to shed some light on the cultural knowledge of Bosnian Serbs living in the Serbian diaspora. More specifically, by combining elements of cognitive anthropology, the anthropology of migration and EU studies, I aim to examine cultural representations regarding the EU among Serbs from the Republic of Srpska living in Graz. How do those people who are "almost like ourselves" (Eriksen 2002: 66) explain the EU integration of Serbia? The narratives of the informants on the EU and on the EU integration of Serbia are in fact narratives of themselves and of their ambivalent relationship with the Republic of Srpska, Austria and Serbia. Therefore, I argue that their interpretations are part of their transnational affiliations to their home country, country of settlement and homeland. Consequently, this research aims to generate a better understanding of the EU from the "bottom-up" perspective often taken in anthropological studies.

2 See for example: Loch 2008; Antonijević 2013; Milosavljević and Antonijević 2015; Antonijević and Milosavljević 2016.

3 See: Serbian European Integration Office 2005.

4 The war in Bosnia and Herzegovina (1992-1995) ended with the Dayton Peace Agreement in 1995, signed by the presidents of Bosnia and Herzegovina, Croatia and Serbia (Izetbegović, Tuđman, and Milošević) (see on this issue Andjelic 2003; Velikonja 2003). According to its Constitution, which regulates the peace and stability of the established country, Bosnia and Herzegovina consists of two autonomous entities, the Federation of Bosnia and Herzegovina and the Republic of Srpska (Article 3). The majority of the Serbian population today lives in the Republic of Srpska. In addition to citizenship of each entity, citizens of both entities have citizenship and passports of Bosnia and Herzegovina (Article 7, a, e). All quoted informants were from the Republic of Srpska entity and they referred to the Republic of Srpska as their home country. Sometimes I refer to them as to "Bosnian Serbs" which serves as an umbrella term.

5 Serbs from the Republic of Srpska are in many instances similar to Serbs originating from Serbia in Graz. They are members of the Serbian Orthodox Church, speak the same language and attend same or similar cultural societies (see Brujić 2018: 169). On the other hand, they have either Austrian or Bosnian citizenship and originate from a country other than Serbia. Bosnia and Herzegovina, in this regard, follows its own EU integration model. From 2003 Bosnia and Herzegovina is a potential candidate country for EU membership and in 2016 the country submitted its application to join the European Union (European Commission 2016). 


\section{Theoretical and methodological approaches}

In order to understand how the EU is viewed by certain Serbs who decided to live in Austria, I utilised an eclectic approach, using mixed methodologies with their foundations first and foremost in migration studies, cognitive anthropology and EU studies.

Currently widely spread theories regarding migrants stem from approaches based on diaspora and transnationalism (Koser 2007: 24-27). Although the meaning of the term diaspora was originally used to refer to forcibly displaced groups, such as, for example Jews, Africans, Irish and Armenians, from the middle of the 1980s this term started to include many other groups (Cohen 1997: ix). In academic, political and public discourse, the diaspora concept includes immigrants, refugees, working migrants, ethnic minorities, overseas communities, different migrant organizations or societies which participate in and materially aid the political, social and cultural life of the home country or local home country community (Ang 2005: 82; Koser 2007: 26, 48-49). Although the Law on Diaspora and Serbs in the Region (2009: Article 2, Article 4) makes a difference between Serbian diaspora (Serbian immigrant communities) and Serbs in the "region" (Croatia, Slovenia, Bosnia and Herzegovina, Hungary, Montenegro, FYR of Macedonia, Albania, Romania) the goal is the same: to maintain cultural, historical, religious and ethnic ties to members of the Serbian population, protect their rights and improve their position in the countries they are living in. Nonetheless, here I would like to raise the following question - to which diaspora do Bosnian Serbs living in Austria belong? The narratives of my informants revealed that they felt attached to the Republic of Srpska, Austria and Serbia.

I found a transnational approach useful in explaining issues regarding EU integration because all informants primarily have relationships with the Republic of Srpska and Austria. In summary, "transnational migration is the process by which immigrants forge and sustain simultaneous multi-strand social relations that link together their societies of origin and settlement" (Glick Schiller et al. 1995: 48). This "simultaneous embeddedness" in several societies (ibid.) is facilitated by modern technology and telecommunication, cheap international travel and the process of globalization (for more details, see Vertovec 2009: 14-15). As Vertovec (2009: 3) explains

"When referring to sustained linkages and ongoing exchanges among nonstate actors based across national borders - businesses, non-governmentorganizations, and individuals sharing the same interests (by way of criteria such as religious beliefs, common cultural and geographic origins) - we can differentiate these as 'transnational' practices and groups (referring to their links functioning across nation-states). The collective attributes of such 
connections, their processes of formation and maintenance, and their wider implications are referred to broadly as 'transnationalism'."

One feature of the transnational life of migrants is bifocality, or an "ongoing sense of double belonging" (Vertovec 2004: 974-975). However, in many cases, such "here and there" belonging is often "neither here, nor there", "foreigner here and foreigner there" or "betwixt and between" the society of origin and the society in which they live (Čapo Žmegač 2007: 286; Simsek-Çaglar 1994: 90-98; Antonijević 2013). Betwixt and between which countries are Serbs originating from Bosnia and Herzegovina, who live in Austria? What can their experience-based knowledge of the EU tell us about Serbia and its EU orientation?

Although Levitt and Glick Schiller (2004: 1012) consider multi-sited research as best suited for research into transnational experiences, they agree that "the impact of transnational relations can be observed by asking individuals about the transnational aspects of their lives, and those they are connected to, in a single setting". Therefore, in order to analyse cultural representations of the EU and of Serbia's EU integration, in February 2013 I conducted semi-structured interviews using a snowball methodology for gathering informants among Serbs in Graz. I did not define filter questions, ${ }^{6}$ believing that only Serbs from Serbia would be interested in and find themselves relevant to discuss the Serbian position. Nonetheless, a typical problem when using a snowball method is the emergence of misunderstandings regarding the nature of the research (Oliver 2006: 281-282). Even a Serbian Orthodox priest whom I interviewed, and who is also originally from the Republic of Srpska, said to me that everyone in the Republic of Srpska feels "as Serbs from Serbia, no matter what. [...] We feel that way and that is the story that should be promoted".

Thus, in this article I discuss the narratives of ten Serbs from the Republic of Srpska (nine male and one female), born between 1959 and 1979, who came to Austria in the period stretching from 1988 to 2003 either due to safety-related reasons, or for economic and/or academic reasons. Only one informant is highly qualified, while the others have primary or secondary level education. I view their narratives on the EU integration of Serbia in light of their historical, personal, cultural and religious ties to Serbia and the Republic of Srpska.

Besides taking a transnational approach, as used in the anthropology of migration and migration studies in general, I also interpret the narratives of Bosnian Serbs from the standpoint of cognitive anthropology. Cognitive anthropology explains how "knowledge [is] used in ordinary life [...] and [...] conventionalized into culture" (D’Andrade 2003: xiv). D’Andrade (2003: 1) furthermore describes

6 Put simply, filter questions "sort out" relevant from irrelevant respondents for conducting research (Knäuper 1998: 70). 
the goal of cognitive anthropology as attempting to understand "how people in social groups conceive of and think about the objects and events which make up their world". Thus, people use cultural, experience and knowledge based notions for understanding the world around them. As a result, in his anthropological analysis on cultural representations of the EU among highly educated Serbs living in Serbia, Žikić defines cultural representations as value- and emotion-laden "cognitive tools" for describing socio-cultural phenomena, which include factual knowledge, stereotypes, personal views etc. (Žikić 2013: 5, 11, 19, 55). Therefore, in this paper I discuss what can we learn from the narratives of Bosnian Serbs living in Graz in regard of their views on the EU and Serbia's EU integration.

\section{Betwixt and between the Republic of Srpska, Austria and Serbia}

This research draws on several previous anthropological studies of cultural representations regarding the EU among Serbs, conducted over the course of the country's EU integration process. In this vein, these cultural representations of the EU reveal - at the same time - representations of Serbia which include aspects such as an idealization of the West, the EU and the SFRY. However, these are accompanied by critiques of the EU and of the current Serbian system (Radović 2009; Žikić 2013; Brujić 2015a, 2015b). To illustrate this, qualitative research into cultural representations of the EU, Europe and the West among secondary school pupils, university students (Radović 2009) and highly educated citizens living in Serbia (Žikić 2013) show that the majority of respondents are pro-EU oriented. The positive aspects of Europe and the "West", which are in most cases equalized with the EU, include a high standard of living, economic development, legal and social justice, and a quality infrastructural and education system. These elements are recognized as lacking in Serbia, and therefore some informants hope that they will develop when Serbia becomes part of the EU. In contrast with these results, Serbs from Serbia who have settled in Slovenia or Austria (Brujić 2015a, 2015b) have an awareness of numerous negative aspects relating to life in the EU. For instance, many believe that life in Austria or Slovenia became harder after joining the EU, and many commented on the discrimination of Serbs and other "Southerners". More specifically, some informants were afraid that the EU would exploit the Serbian market and force Serbia to accept Kosovo's proclamation of independence. However, nobody I spoke to planned to return, and many had even decided to take Austrian or Slovenian citizenship, in so doing abandoning their Serbian citizenship. The informants I spoke to found that these countries were economically, legally, administrative, legislative, and socially better regulated. In this respect, they hoped that joining the EU would further improve these aspects and facilitate work and educational mobility in Serbia, as well as the ability to travel more. 
Serbian respondents from the Republic of Srpska gave comparable responses and had similar impressions of the EU. None of the informants interviewed planned to go to live in Serbia, although many noticed and/or experienced similar discrimination towards Serbs and "Southerners". Indeed, Austria has frequently been criticized for its "anti-immigrant sentiments" (MIPEX 2015). Although Austria joined the European Union in 1995 and accepted the euro as a currency in 1999, due to Austria's "right-wing" politics, the country was placed under sanctions during 2000 (Falkner 2001: 11-13). The majority of informants plan to return to their hometowns when they retire. This idea or wish to return is very common among migrants, especially among guest workers, and is discussed in the literature as their concrete (but often unaccomplished) "plan to return" or "myth of return" since, as in other contexts, the majority never actually went back (Simsek-Çaglar 1994; Čapo 2012: 41, 44). To illustrate this, one informant ${ }^{7}$ who came to Austria just before the war in 1991 said he would like to go back to his hometown in the Republic of Srpska where he owns a house. However, due to the educational and career options for his children being better in Austria and in the EU in general, he decided to postpone the return until his retirement. He holds the opinion that life in Austria was better before entering the EU, and that Serbia (and the Republic of Srpska likewise) was better off not being in the Union:

"The changes happened overnight when the euro was introduced. It was extreme. [...] [E]verything became more expensive. It became more difficult to find a job."

Another informant who arrived with his family in 1989 for economic reasons has similar views. According to him, it was a mistake for Austria to become a part of the EU, because prices increased. Like some other respondents, he also noticed that Austria used to be strong: a legally and economically developed country, which was well organized politically before its accession to the EU. He also decided not to go back while his children, who had already "become Austrians", were rooted in Austria. On the other hand, he reported missing his home in the Republic of Srpska and thinks that "there is nothing nicer than to be in the place where one was born". Although he has had Austrian citizenship since 2001, he says "I'm a foreigner here and I have remained a foreigner". From his perspective, Serbia should not integrate with the EU:

"But there is one thing I don't understand. Why does Serbia want to join the EU so much when Serbia is already in the EU? And who can throw it out of Europe? [laughs]. [...] Look, at the start they [Serbs] will receive financial help

In accordance with ethical procedures in the social sciences (Israel and Hay 2006), all personal information which is not crucial for the analysis made in this paper is hidden. 
from the EU, saying 'we got the cash' [...] And when they enter, only then they [the EU countries] will begin to demand their money back, but not what they gave but several times more."

Some other informants would also like to return. For instance, an informant who came in 1988 would gladly return to the Republic of Srpska if the economic situation were better. On the other hand, he said that Serbia should enter the EU if accepting the independence of Kosovo was not a condition:

"Yes [for the EU integration of Serbia], but not at the cost of Kosovo. Well, that is my cradle, my homeland. [...] No, it is better if we stay down there, where we are, even if no Serbs remain. And Kosovo not at any cost."

A Bosnian Serb who does not want to take Austrian citizenship also feels as if he is both "here and there". His family is having a better time in Austria and his children were born there, yet he longs for his home in the Republic of Srpska. He explains that "it seems as if we now have two houses. Not just two houses but two homes". He is surprised with the Serbian EU orientation:

"I'm just wondering, whether they will, let's say, completely milk out Serbia. They will drain it for years and they will always find something [...] Now Kosovo, before Mladić, before Mladić Karadžić, tomorrow they will say 'you're not beautiful', the day after they will say 'you're not well dressed'. And we always dance to their tune. Yet we never arrive! Neither we nor our children will arrive. [...] we should start to think about our house, work as you know, as you can."

This view on exploitation was repeated in other interviews as well:

"Serbia will not gain any considerable benefit from it, because Europe is like that, it gives its stores, sends its banks, everything so that it can slowly milk everything."

The only highly educated informant who came in 2003 for school, then remained in Austria, narrates that the EU operates

"so that large countries like France and Germany can primarily fulfil their interests. They place their goods, they invest their capital and all they need, their banks will come here, their companies will come here [into smaller countries] and they simply squeeze out all that the country has [...] You can introduce whatever laws you like. The law exists here and there in Serbia. However, the standard [of living] is that which leads the law to be respected or not. If you have a high standard [of living] and you are hit in your wallet, the next time you will ask yourself 'shall I drive home drunk next time'. [...] I 
don't believe that Serbia will have much use of it [the EU]. Its standards will be raised temporarily, but in the long run, there's nothing there."

However, although being against the EU integration of Serbia, many informants acknowledge positive changes. The most important ones relate to laws and benefits for young people. For instance:

"It [joining the EU] will mean a lot to young people as it will mean more job positions. There is a lack of jobs down in Serbia. Young people are, you know, unemployed, there are no jobs, nowhere to work. [In the EU] there is a bigger market. [After joining the EU] some will go to Austria, some to Germany, some will go to England. [...] for those who know another language, it will be no problem. [...] young people and school pupils will go to the West without visas [...] and find a job. [...] In the EU you can travel without borders, no traffic jams, all of that is in order. As I said, it will offer better prospects for younger people. And for those who are middle-aged and who work in firms, they won't get a bigger salary. I don't believe that the standard will increase so quickly."

The informant who came to Austria "to seek his fortune" in 1991 would like to go back to the Republic of Srpska. However, he knows that this is a futile idea. As with the earlier mentioned informants, he also wants to provide for his family the best he can. Moreover, he believes that "the conditions should be created" in the Republic of Srpska so that he can go back there. He thinks that the EU stands for the economic invasion of small countries.

"It's a pure [economic] invasion of these poor countries by the EU. [...] It means, it takes your factories, it takes your land. [...] You are its slave [i.e. of the EU]. And when it takes your factories and land it's over. You have nothing of your own."

On the other hand, he notices that:

"The only advantage would be their laws, I think. They have very good, nice laws. [...] But they are disciplined people; they stick to these laws and are afraid of them. [...] This means that the penalties force people to be disciplined. I'm not absolutely against Serbia's entrance. That would be insolent of me, given that I live in Austria and work and make money here, while they, down there, are suffering. [...] If we want to enter the EU, let's find a nice way, and not be blackmailed [...] they can't say that you cannot have that many dairy cows and that you can only have a thousand [...] They cannot limit how many plums, apples or pears you can have. If they limit you, then that is not justice. If they limit how much you can have why would I need that EU? Only reciprocity.” 
What is the general impression the informants give, based on their experience, of the EU? While only one (and the only female) informant ${ }^{8}$ had an ambivalent attitude towards entering the EU, all others believed that Serbia would do better out of the European Union. Consequently, the informants draw differences between Austria and the EU. Not only do they state that Austria had a higher economic standard before it joined the EU, but according to the informants' opinions, it was stable enough not to be exploited by the EU as a supra-national organization. According to the informants, the EU has the political and financial means to demand and impose on Serbia what it will in order to take advantage of it. These notions run parallel with Petrovićs (2009: 53) remark on "colonial" discourse concerning the Western Balkans:

"The idea that some kind of colonial administration in the Balkans is indispensable to maintain peace and enable the development of the entire European continent was frequently echoed in journal articles, essays and pseudo-academic literature dating from the 1990s."

Petrović ties these ideas regarding economic, security and peacetime surveillance of the Balkans by EU countries to political discourse. Serbian informants in Austria, on the other hand, have a fear of perpetuating power relations, including exploitation and control over the Serbian market (see also Brujić 2015b: 39), which are similar to policies used in colonies. ${ }^{9}$ In addition, this "never-ending" migrant position that the informants occupy, is simultaneously the source of their cultural proficiency in understanding Austria, Serbia, the EU and the process of Serbia joining "Europe". They are "almost Austrians", "almost Serbs" and "almost Europeans". As Chambers (1994: 6) explains this "habit of living between worlds":

8 She came to Austria in 1992 with her boyfriend (today husband) and has had Austrian citizenship since 2002. The reflections upon the EU integration of Serbia of this informant are similar to the ones of other females descending from Serbia. Namely, all of them were born at the beginning of 1970 s, they came initially with their partners or husbands and they have children. In this respect, their attitudes towards the EU are general, sometimes very vague and ambivalent, emotional and/ or related to the future of (their) children, in other words, to the benefits of the EU for their children (see Brujić 2018: 121-128).

9 Although Serbia and other Balkan countries are de facto European, a scholar who wrote about the EU integration process of Slovenia, Velikonja (2005: 26), used Bhabha's concept of "colonial mimicry", to explain this paradoxical position: "How, then, is it possible that 'we are becoming part of it now', if 'we have always been part of it'? [...] [T] he colonized natives are almost the same, but not quite the same as their colonizers, i.e., the members of the 'ruling', and hence, naturally, 'higher' culture. [...] The situation in which the Slovenes (and other newcomers to Europe) found themselves within this new Eurocentric meta discourse is one in which we are 'almost European, but not quite European'; or, in other words, 'soon to be Europeanized Non-Europeans, who still have to learn a lot about being European'”. 
"To come from elsewhere, from 'there' and not 'here', and hence to be simultaneously 'inside' and 'outside' the situation at hand, is to live at the intersections of histories and memories, experiencing both their preliminary dispersal and their subsequent translation into new, more extensive, arrangements along emerging routes. [...] This drama, rarely freely chosen, is also the drama of the stranger. Cut off from the homelands of tradition, experiencing a constantly challenged identity, the stranger is perpetually required to make herself at home in an interminable discussion between a scattered historical inheritance and a heterogeneous present."

As narratives on the EU integration of Serbia illustrate, the informants are attached to the Republic of Srpska, Austria and Serbia - as an outcome of their dislocated position. Their cultural representations on the EU and EU integration of Serbia, reaffirmed by their lived experience, presumptions, speculations and personal opinions, are part of their self-understanding and self-approval of their own position (staying in Austria). Although they are only "here" in Austria and "there" in the Republic of Srpska, as ethnic Serbs they feel also that they are part of Serbian society. These multiple attachments to several countries: home country (the Republic of Srpska), country of settlement (Austria) and homeland (Serbia) reveal their ambivalent position. They are Serbs, born in the former Socialist Republic of Yugoslavia, who are now living in the Serbian diaspora. However, due to the wars and disintegration of the country, they became the citizens of other countries. To explain this further, since they do not originate from Serbia, they are not part of "Serbian diaspora" and since they do not live in Bosnia and Herzegovina, they are not recognized as Serbs in the "region" as defined by Serbian Law on Diaspora and Serbs in the Region. Their non-existent position within the law reveals and is, at the same time, the outcome of the emergence of new national states and changes of group identities and boundaries in the Balkans. In other words, not only are they "others" in Austria, they are "others" as regards Serbian law and Serbia, which is their historical, ethnic, religious, cultural etc. source of collective and personal identity. ${ }^{10}$ Therefore, this example affirms the notion that diasporas are heterogeneous

10 One prominent example of maintaining ethnic, cultural, historical, and religious connection of the Republic of Srpska with Serbia, i.e. the periphery of Serbian ethnic and cultural identity with its centre, is through the change of urban toponyms after Dayton Peace Agreement. Namely, Radović focuses on symbolical identity transformations of cities in the former Yugoslavia through the reconstruction of public spaces (Mostar, Priština, Banja Luka and East Sarajevo, for example). Using the examples of re-naming the streets and erecting and reconstructing Serbian Orthodox churches and monuments in East Sarajevo and in the capital of the Republic of Srpska, Banja Luka, the author reveals its symbolical purpose. That is, to ethnically delineate (Serbian) space in a nation building process. As Radović observes, the streets in Banja Luka and East Sarajevo were "ethnically and ideologically cleansed" from Muslim and Croatian influences, while the majority of new toponyms, street names and monuments are connected with Serbian history, culture and its allies (Radović 2013: 143-188). 
and hybrid communities that have local/domestic and transnational ties (Werbner 2005: 470). Povrzanović Frykman (2004: 85), thus, opts to use "diasporic" (experience, for instance) instead of diaspora:

"Using the adjective diasporic instead of the noun diaspora (referring to social formation) hints at processes of identity formation. It keeps the research interest open towards a wide range of experiences of what is often presented as 'living away from home', or, from a transnational perspective, as having yet another home(land) - whether actual, remembered, or imagined - as a potential or actual frame of emotional, social or political reference."

As Simsek-Çaglar in her anthropological analysis of German Turks in Berlin explains, Turkish displacement influenced their understanding of place: "A new sense of place shaped by having more than one home has evolved, an identity placed in more than one location" (1994: 66). In this respect, these Bosnian Serbs respondents simultaneously belong and are "out-of-place" (Čapo Žmegač 2008: 333) in Austria, the Republic of Srpska and Serbia. Thus, it is possible to say that they do not live bifocal but multifocal lives. This "out-of-place-ness" enables them to justify their own settlement in Austria instead of returning to the economically poorer Republic of Srpska, to comment on the quality of life in the European Union, and to have an opinion on Serbia's EU integration.

I found Levitt's and Glick Schiller's explanation of "ways of belonging" and "ways of being" in the transnational social field useful for understanding informants' positioning. According to them (Levitt and Glick Schiller 2004: 1009), while the social field is "a set of multiple interlocking networks of social relationships through which ideas, practices, and resources are unequally exchanged, organized, and transformed", "transnational social fields connect actors through direct and indirect relations across borders". Within the transnational social field, "ways of being" and "ways of belonging" play an important role in shaping social and cultural interaction and the formation of a person's identity. In this respect, "ways of being" only represent a person's social practices and connections within the transnational social field and "ways of belonging", the persons' cultural or national identification with some specific group. The authors explain that "ways of being" in the social field are "actual social relations and practices that individuals engage in [...] but do not identify themselves with any label or cultural politics associated with that field" (ibid.: 1010). On the other hand, "ways of belonging", mediated through memory, nostalgia, imagination, or ideas, objects and information that spans across several societies "refers to practices that signal or enact an identity which demonstrates a conscious connection to a particular group" although people do not have to have actual social relations with the identified group (ibid.: 1010-1011). I argue that ethnographic research of transnational practices of four families of Bosnian Croats who found their refuge in Sweden during 1990s 
(Povrzanović Frykman 2011) is an example of a "transnational way of being" and narratives of Bosnian Serbs living in Graz an example of a "transnational way of belonging". Namely, these Bosnian Croats are connected with three countries: with Bosnia and Herzegovina from which they originate, with Sweden where they live and Croatia, as a country of their ethnic belonging, and where they have bought summerhouses on the Croatian coast. In other words, they live in Sweden, visit their family in Bosnia and Herzegovina and spend holidays in Croatia. Povrzanović Frykman (2011:254) explains that Croatia became their "third homeland", due to their regular visits. Thus the author speaks of "the normality of their practices of connection, and [...] multiple locations" grounded in their personal transnational experiences. These transnational experiences "connect the places of their daily life to other places to which they are socially and emotionally attached, that happen to be located in three countries" (ibid.: 242). On the other hand, the narratives of Serbs from the Republic of Srpska on EU integration of Serbia and Kosovo are part of their historical memory, cultural knowledge and shared remembering of a homeland (see Putinja and Stref-Fenar 1997: 184, 186-187) - i.e. they are expressions of their "way of belonging" and their transnational connections to Serbia. While this "transnational way of belonging" describes how these Bosnian Serbs experience their attachments to Serbia, their understandings of the European Union reveal their dislike of the EU which is seen as exploiting small, economically weak countries, such as Serbia.

\section{Concluding remarks}

In Serbian ethnology and anthropology, the issue of cultural representations of the EU among Serbs living in Serbia or among the diaspora has already been studied. However, in this paper, the main research group considered are Serbs from the Republic of Srpska living in Graz, and their views on the EU and the integration of Serbia into the EU. Although the issues of Bosnian Serbs living among the (Serbian and Bosnian) diaspora open up many more research questions, including the issue of ethnic identity, assimilation, EU integration of Bosnia and Herzegovina, female migration, war narratives etc., these issues constitute topics for further study. I have therefore chosen to focus this study on them as they have a permanently ambivalent status - being neither fully integrated "here" in Austria nor living "there" in the Republic of Srpska nor Serbia. Their cultural representations of the EU and of the EU integration of Serbia are not only "cognitive tools" for understanding the situation in Serbia, but serve consequently as a "transnational way of belonging" in Serbia. As they are Serbian co-ethnics originating from Bosnia and Herzegovina, and having either Bosnian or Austrian citizenship, they are neither part of the Serbian diaspora, nor part of the Serbian "region" in a formal sense. They are members of Bosnian diaspora and thus pro- 
tected by the Republic of Bosnia and Herzegovina (Constitution, Article 7, e). In this respect, their cultural representations of the EU and of the EU integration of Serbia are products of this ambivalent relationship because none of them plan at present to go back to the Republic of Srpska nor to move to Serbia. Therefore, as they are "simultaneously 'rooted and rootless" (Trinh T. Minh-ha 1990 quoted in Chambers 1994: 95) the stories on the EU integration of Serbia are for them at the same time stories of their own (non)-integration and a confirmation of their ethnic and cultural identity which binds them to Serbia, Austria and the Republic of Srpska.

Levitt and Glick Schiller (2004: 1010) explain that transnational "ways of belonging" can only be "concrete, such as wearing a Christian cross or Jewish star" rather than symbolic. On the contrary, in this paper I demonstrate that their ideas and cultural conceptions of EU integration of Serbia play a "concrete role" - to reaffirm them as Serbs and link them with Serbia, their ethnic, religious and cultural home state. In other words, their cultural representations serve to convert a space (Serbia as their historical homeland) into a concrete place: the place of their ethnic and cultural origin. They live and work in Austria and go to the Republic of Srpska for vacation, where they would like to return after they retire (although they are aware that they will probably never come back). Their narratives on Serbia and Kosovo are, thus, part of their group memory on their mythical homeland and ethnic identification. More precisely, their narratives state that homeland does not have to refer to one place but includes multiple homelands, such as mythical, historical, ethnic, ancestral etc. homelands. 


\section{REFERENCES}

Andjelic, Neven. 2003. Bosnia-Herzegovina. The End of a Legacy. London, Portland: Franc Cass.

Ang, Ien. 2005. "Diaspora". In New Keywords. A Revised Vocabulary of Culture and Society. Tony Bennett, Lawrence Grossberg and Meaghan Morris, eds. Malden, Oxford, Victoria: Blackwell Publishing, 82-84.

Antonijević, Dragana. 2013. Stranac ovde, stranac tamo. Antropološko istraživanje kulturnog identiteta gastarbajtera [Stranger Here, Stranger There. Anthropological Research of Cultural Identity of Guest Workers]. Beograd: Srpski genealoški centar, Odeljenje za etnologiju i antropologiju Filozofskog fakulteta.

Antonijević, Dragana and Ljubica Milosavljević. 2016. "Starost gastarbajtera. Strategije životnih izbora migrantske populacije u penziji” [Gastarbeiters' Old Age. Strategies of Life Choices among the Migrant Population of Pensioners]. Етноантрополошки проблеми 11/1: 113-135.

Baldaszti, Erika, Regina Fuchs, Josef Kytir, Stephan Marik-Lebeck, Peter Alexander Rumpolt, Alexander Wisbauer and Heinz Faßmann. 2015. Migration \& Integration. Zahlen. Daten. Indikatoren [Migration \& Integration. Numbers. Data. Indicators]. Wien: Statiskik Austria. Kommission für Migrations- und Integrationsforschung der Österreichischen Akademie der Wissenschaften.

Brujić, Marija. 2015a. “'Tako blizu, a tako daleko'. Kulturne predstave o evrointegracijama Srbije među iseljenicima u Ljubljani" ["So Close, and Yet So Far". The Cultural Notions on EU Integration of Serbia among Immigrants in Ljubljana]. Etnološkoantropološke sveske 25/14: 7-28.

Brujić, Marija. 2015b. "Da li je 'princeza gola’? Kulturne predstave iseljenika u Beču o evrointegracijama Srbije" [Is the "Princess Naked"? Cultural Representations of Migrants in Vienna about European Integration of Serbia]. Antropologija 15/3: 23-46.

Brujić, Marija. 2018. Kulturne predstave o Evropskoj uniji i evrointegracijama Srbije mecu pripadnicima srpske dijaspore u Gracu [Cultural Representations of the European Union and Serbian EU Integration among the Serbian Diaspora in Graz]. Beograd: Univerzitet u Beogradu, Filozofski fakultet, Odeljenje za etnologiju i antropologiju, Dosije studio.

Chambers, Iain. 1994. Migrancy, Culture, Identity. London, New York: Routledge.

Cohen, Robin. 1997. Global Diasporas. An Introduction. London: UCL Press.

Cohen, Robin. 2001. "Diasporas". In International Encyclopedia of the Social \& Behavioral Sciences. Neil J. Smelser and Paul B. Baltes, eds. Palo Alto, Berlin: Elsevier Science Ltd., 3642-3645.

Constitution of Bosnia and Herzegovina. http://www.ccbh.ba/public/down/USTAV BOSNE_I_HERCEGOVINE_engl.pdf (last access 23 October 2017).

Čapo Žmegač, Jasna. 2007. "Encounters in the Transnational Social Space". In Places of Encounter. In Memoriam Borut Brumen. Rajko Muršič and Jaka Repič, eds. Ljubljana: Zupaničeva knjižnica, 277-290. 
Čapo Žmegač, Jasna. 2008. "Parochial Transnationals. Being of Croatian Descent in Germany". In Dynamics of National Identity and Transnational Identities in the Process of European Integration. Elena Marushiakova, ed. Newcastle: Cambridge Scholars Publishing, 323-338.

Čapo, Jasna. 2012. “'Not a Soul Can Plan to Return for Sure!' Double Homing Desire of Croatian Migrants in Germany". In Migration and Identity. Historical, Cultural and Linguistic Dimensions of Mobility in the Balkans. Petko Hristov, ed. Sofia: Paradigma, 38-47.

D'Andrade, Roy. 2003. The Development of Cognitive Anthropology. Cambridge: Cambridge University Press.

Eriksen, Hylland Thomas. 2002. Ethnicity and Nationalism. Anthropological Perspectives. London, Sterling: Pluto Press.

European Commission. 2016. Bosnia and Herzegovina. https://ec.europa.eu/neighbourhood-enlargement/countries/detailed-country-information/bosnia-herzegovina_ en (last access 24 October 2017).

Falkner, Gerda. 2001. "The Europeanisation of Austria. Misfit, Adaptation and Controversies". European Integration Online Papers (EIoP) 5/13. http://eiop.or.at/ eiop/texte/2001-013a.htm (last access 21 June 2015).

Glick Schiller, Nina, Linda Basch and Cristina Szanton Blanc. 1995. "From Immigrant to Transmigrant. Theorizing Transnational Migration". Anthropological Quarterly 68/1: 48-63.

Grečić, Vladimir and Marko Lopušina. 1994. Svi Srbi sveta [All the Serbs in the World]. Beograd: Princip.

Israel, Mark and Iain Hay. 2006. Research Ethics for Social Scientists. Between Ethical Conduct and Regulatory Compliance. London, Thousand Oaks, New Delhi: SAGE Publications.

Ivanović, Vladimir. 2012. Geburtstag pišeš normalno. Jugoslovenski gastarbajteri u SR Nemačkoj i Austriji 1965-1973 [You Write Geburtstag Normally. Yugoslav Guest Workers in the Federal Republic of Germany and Austria 1965-1973]. Beograd: Institut za savremenu istoriju.

Knäuper, Bärbel. 1998. "Filter Questions and Question Interpretation Presuppositions at Work". Public Opinion Quarterly 62: 70-78.

Koser, Khalid. 2007. International Migration. A Very Short Introduction. Oxford, New York: Oxford University Press.

"Law on Diaspora and Serbs in the Region". 2009. Official Gazette of the Republic of Serbia 88. http://www.dijaspora.gov.rs/wp-content/uploads/2014/04/LAW-ondiaspora-and-Serbs-in-the-Region.pdf (last access 26 December 2016).

Levitt, Peggy and Nina Glick Schiller. 2004. "Conceptualizing Simultaneity. A Transnational Social Field Perspective on Society". International Migration Review 38/3: 1002-1039.

Loch, Susanne. 2008. "Ankommen und züruckzukeheren”. Eine kulturanthropologische Studie zur Remigration serbischer Gastarbeiter am Beispiel Donje Vidovo ["The Arrival 
and the Returning Home". The Cultural Anthropological Study on Re-Migration of Serbian Guest Workers on the Example of Donje Vidovo]. MA thesis. Graz: Institut für Volkskunde und Kulturanthropologie, Karl-Franzens Universität.

MIPEX - Migrant Integration Policy Index. 2015. Austria. http://www.mipex.eu/austria (last access 25 December 2016).

Milosavljević, Ljubica and Dragana Antonijević. 2015. "Starački domovi kao perspektiva realnosti starih gastarbajtera" [Nursing Homes as the Perspective and Reality of Guest Workers in Old Age]. Етноантрополошки проблеми 10/2: 333-355.

Oliver, Paul. 2006. "Snowball Sampling". In The Sage Dictionary of Social Research Methods. Victor Jupp, ed. London, Thousand Oaks, New Delhi: SAGE Publications, 281-282.

Payer, Peter. 2004. "'Gehen Sie an die Arbeit'. Zur Geschichte der 'Gastarbeiter' in Wien 1964-1989" ["You Go to Work". On the History of "Guest Workers" in Vienna 1964-1989]. Wiener Geschichtsblätter 1: 1-18.

Petrović, Tanja. 2009. A Long Way Home. Representations of the Western Balkans in Political and Media Discourses. Ljubljana: Peace Institute.

Povrzanović Frykman, Maja. 2004. "Transnational Perspective in Ethnology. From 'Ethnic' to 'Diasporic' Communities”. In Transnational Spaces. Disciplinary Perspectives. Maja Povrzanović Frykman, ed. Malmö: Malmö University, International Migration and Ethnic Relations, 77-100.

Povrzanović Frykman, Maja. 2011. "Connecting Three Homelands. Transnational Practices of Bosnian Croats Living in Sweden". In The Bosnian Diaspora. Integration in Transnational Communities. Marko Valenta and Sabrina P. Ramet, eds. Farnham, Burlington: Ashgate, 241-259.

Putinja, Filip and Žoslin Stref-Fenar. 1997. Teorije o etnicitetu [Theories of Ethnicity]. Beograd: XX vek.

Радовић, Срђан [Radović, Srđan]. 2009. Слике Европе. Истраживате представа o Европи и Србији на почетку XXI века [Images of Europe. Research of Representations of Europe and Serbia in Early 2000s]. Београд: Етнографски uнституm CAHY.

Radović, Srdan. 2013. Grad kao tekst [City as Text]. Beograd: Biblioteka XX vek.

Serbian European Integration Office. 2005. National Strategy of Serbia for the Serbia and Montenegro's Accession to the European Union. Draft Version. Government of the Republic of Serbia. http://www.seio.gov.rs/upload/documents/nacionalna_dokumenta/national_strategy-pdf.pdf (last access 30 December 2016).

Simsek-Çaglar, Ayse. 1994. German Turks in Berlin. Migration and Their Quest for Social Mobility. PhD thesis. Montreal: McGill University, Department of Anthropology.

Velikonja, Mitja. 2003. Religious Separation and Political Intolerance in Bosnia-Herzegovina. College Station: Texas A\&M University Press.

Velikonja, Mitja. 2005. Eurosis. A Critique of the New Eurocentrism. Ljubljana: Peace Institute. 
Vertovec, Steven. 2004. "Migrant Transnationalism and Modes of Transformation". International Migration Review 38/3: 970-1001.

Vertovec, Steven. 2009. Transnationalism. London, New York: Routledge.

Werbner, Pina. 2010. "Transnationalism". In Encyclopedia of Social and Cultural Anthropology. Alan Barnard and Johnatan Spencer, eds. London, New York: Routledge, 698-701.

Žikić, Bojan. 2013. Slike u izlogu. Kulturne predstave o Evropskoj uniji kao sredstvo opisivanja paralelne stvarnosti stanju u Srbiji 1991-2011 [Shop Window Reflections. Cultural Notions of EU as a Tool for Representing the Reality Comprehended as Parallel to the One of Serbia 1991-2011]. Beograd: Srpski genealoški centar, Odeljenje za etnologiju i antropologiju Filozofskog fakulteta. 